\title{
ЛИЧНОСТНЫЕ ПРЕДИКТОРЫ ПРОАКТИВНОСТИ У БОЛЬНЫХ ПАРАНОИДНОЙ ШИЗОФРЕНИЕЙ
}

\begin{abstract}
Аннотация. Автор рассматривает проактивность как устойчивую характеристику зрелой личности, в норме проявляющуюся в самодетерминированном поведении, в готовности активно воздействовать на условия среды и обстоятельства жизни, в способности прогнозировать определенные события, ставить личностно-значимые чели и стремиться к их достижению. Изучены личностные детерминанты проактивного (самодетерминированного) поведения у лии, страдающих параноидной шизофренией. Уточнено, что определяющими снижение проактивности и ее деструктивизацию у обследованных больных являются такие факторы как дезадаптивные установки в срере межличностного общения, дефицитарность смысложизненных ориентаций (удовлетворенность лишь текущими событиями, редуцированная способность ставить долгосрочные цели, отсутствие ощущения контроля над собственной жизнью, низкие показатели интернальности). Показана роль бредовой симптоматики в искажении паттернов проактивного поведения при шизофрении, актуализирующего тенденции к избеганию социальных контактов и аутизации. Большинство из перечисленных особенностей коррелирует с низкими показателями проактивности, которые, в свою очередь, негативно влияют на уровень социального функционирования больных. Выявленные нарушения автор предлагает рассматривать в качестве мишеней психокоррекционного и психотерапевтического процесса, направленного на восстановление социальных и когнитивных функций у больных шизофренией.

Ключевые слова: проактивность, проактивное поведение, шизофрения, личностные предикторы, смысложизненные ориентации, установки, самодетерминация, интернальность, целеполагание, социальное функционирование.
\end{abstract}

\section{Актуальность}

Согласно статистике В03, на сегодняшний день шизофрения по-прежнему остается одним из самых распространенных и тяжелых психических заболеваний в мире ${ }^{1}$. Так, наряду с психотическими состояниями, грубо дезорганизующими деятельность, исследователи отмечают выраженные нейрокогнитивные изменения ${ }^{2}$, затруднения в распознавании и выражении эмоций ${ }^{3}$, мотиваци-

\footnotetext{
1 Чуркин А.А. Основные тенденции распространенности шизофрении в современном мире / ГНЦ социальной и судебной психиатрии им. В.П. Сербского. М., 2001. 12 с.

2 Акимова Е.В. Характеристика высших психических функций и неврологических расстройств у больных с дефицитарными состояниями при шизофрении. Автореф. дисс. ... канд. мед. наук. н. Новгород, 2005. 23 с.

3 Рычкова О.В. Эмоциональные составляющие нарушений социальной перцепции при шизофрениии. // Социальная и
}

онные нарушения 4 , деструктивные проявления в поведении ${ }^{5}$.

В последние годы особое внимание уделяется изучению особенностей социального функционирования людей, страдающих различными

клиническая психиатрия. 2012. Т. 22. № 4. С. 22-26; Хоменко H.В. Распознавание эмоций и память на лица у пациентов с шизофренией // Психиатрия, психотерапия и клиническая психология. 2012. № 4 (10). С. 46-55.

4 Семенова Н.Д., Фурсов Б.Б. К вопросу о психодиагностике мотивации в психосоциальной терапии и психосоциальной реабилитации шизофрении. Часть I // Социальная и клиническая психиатрия. 2013. Т. 23. № 1. С. 34-39; Фурсов Б.Б. Проблема мотивации и ее нарушений при шизофрении // Социальная и клиническая психиатрия. 2012. Т. 22. № 4. С. 91-100.

5 Кузнецова С.О. Психологические особенности враждебности при психической патологии // Вопросы психологии. 2007. № 5. C. 89-99. 


\section{Клиническая психология}

формами шизофрении ${ }^{6}$. Так, отмечаются нарушения социального взаимодействия, проявляющиеся в семейных взаимоотношениях, конфликтах на работе, постепенно приводящих к отрыву от общества. Исследователи подчеркивают, что большинство проблем, возникающих у больных шизофренией в продромальном периоде, носят социально-психологический характер ${ }^{7}$. Характерными признаками шизофрении являются снижение уровня побуждений и психической активности, трансформации в системе мотивов, нарушения самосознания, межличностного взаимодействия и регуляции социального поведения ${ }^{8}$. При этом отмечается, что при неблагоприятных обстоятельствах и отсутствии адекватной терапии заболевание может быстро приводить к социальной дезадаптации и инвалидизации.

Долгое время в исследованиях шизофрении акцент делался на роли биологических и средовых факторов (нарушение синтеза нейротрансмиттеров, дупликация ДНК-последовательностей, родительское воспитание, урбанизация, безработица, психотравмы и мн. др.). В то же время биопсихосоциальная парадигма в психиатрии и патопсихологии требует системного подхода к оценке факторов, влияющих на формирование личностных нарушений. Сегодня в этиологической структуре психопатологических проявлений все чаще очерчиваются психологические факторы. Однако до сих пор остается дискуссионным вопрос о том, какие именно интрапсихические предикторы инициируют развитие заболевания, какие являются реакцией на психотравмирующие события, а какие выступают в качестве кодетерминант наряду с начавшимися изменениями личностных свойств.

\footnotetext{
6 Левикова Е.В. Социальная компетентность больных шизофренией подростков. Часть 1 // Психологические исследования: электрон. науч. журн. 2010. № 2(10). (http://psystudy. $\mathrm{ru})$; Лоскутова В.А. Социально-когнитивные функции при шизофрении и способы терапевтического воздействия // Социальная и клиническая психиатрия. 2009. Т. 19. № 4; Холмогорова А.Б., Гараньян А.Г., Данлыкова А.А., Шмуклер А.Б. Программа тренинга когнитивных и социальных навыков (ТКСН) у больных шизофренией // Социальная и клиническая психиатрия. 2007. Т. 17. № 4.

7 Гурович Н.Г. Соотношение положительных и отрицательных эмоций у больных шизофренией. Автореф. дисс. ... канд. психол. наук. М., 1986. 23 с.

8 Шостакович В.В., Блохина В.П., Белявский Н.Н. Критерий ранней диагностики шизофрении. Методическое письмо. Днепропетровск, 1972. 25 с.
}

По нашим представлениям, одним из ключевых индикаторов психического здоровья и гармоничного развития личности является проактивность $^{9}$. Основываясь на обзоре современных исследований, затрагивающих данную проблему ${ }^{10}$, мы полагаем, что проактивность представляет собой устойчивую характеристику зрелой личности, выражающуюся в следующих аспектах:

а) в самодетерминированном поведении, т.е. поведении, обусловленном внутренними побуждениями личности, а не внешними стимулами;

б) в готовности активно воздействовать на условия среды в противоположность пассивному к ним приспособлению;

в) в умении прогнозировать наступление определенного жизненного события, а также выстраивать поведенческие стратегии, ориентированные на будущее;

г) в способности ставить значимые цели и стремиться к их достижению.

Необходимо уточнить, что проактивное поведение более двух десятилетий детально исследуется в прикладных отраслях психологического знания. Так, в организационной психологии под проактивностью понимается инициативное поведение трудящихся, ориентированное на инновации и подготовку к возможным проблемным ситуациям $^{11}$. В последние годы получившая широкое распространение в зарубежной психологии теория самодетерминации ${ }^{12}$ развивает идеи о внутренней

\footnotetext{
9 Ерзин А.И. Проблема проактивности в психологии здоровья // NB: Психология и психотехника. 2014. № 1. С. 94124. (http://e-notabene.ru/psp/article_11536.html).

10 Ерзин А.И., Епанчинцева Г.А. Понятие проактивности в современной психологии // Теоретическая и экспериментальная психология. 2013. Т. 6. № 1. С. 79-83; Старченкова Е.С. Ресурсы проактивного совладающего поведения // Вестник Санкт-Петербургского университета. Серия 12: Психология. Социология. Педагогика. 2012. № 1. C. 51-61; Aspinwall, L.G. \& Taylor, S.E. (1997). A stitch in time: self-regulation and proactive coping. Psychological Bulletin, 121, 417-436; Crant, J. M. (2000). Proactive behavior in organizations. Journal of Management, 26 (3), 435-462.

11 Crant, J.M. (2000). Proactive behavior in organizations. Journal of Management, 26 (3), 435-462.

12 Гордеева Т.О. Теория самодетерминации: настоящее и будущее. Часть 1. Проблемы развития теории // Психологические исследования: электронный научный журнал. 2010. № 4(12). C. 11; Deci, E.L., Vansteenkiste, M. (2004). Selfdetermination theory and basic need satisfaction: Understanding human development in positive psychology // Ricerche di Psichologia, 27, 17-34.
} 
обусловленности человеческого поведения, что, безусловно, связано с проблемой проактивности. Ряд авторов ${ }^{13}$ подчеркивает значение проактивности в поддержании физического здоровья, например, в рамках т.н. теории благополучного старения (successful aging theory), фокусирующей внимание на физическом, душевном и социальном благополучии в позднем возрасте. Доказывается роль проактивности в процессе преодоления трудных жизненных обстоятельств, потенциально угрожающих личностным ресурсам и самоактуализации ${ }^{14}$. Однако, несмотря на большой массив теоретических и эмпирических данных о проактивности, этот феномен, как нам представляется, еще не достаточно раскрыт в клинической психологии.

Ранее мы показывали ${ }^{15}$, что при некоторых психических заболеваниях проактивность заметно снижена по сравнению с нормой. Тем не менее, более детальный анализ позволил бы уточнить, какие именно личностные нарушения связаны со снижением проактивности. Таким образом, целью настоящего исследования явилось изучение отдельных личностных предикторов у больных шизофренией, обуславливающих снижение проактивности и нарушение социального функционирования.

\section{Материалы и методы}

Клинико-психологически и экспериментальнопсихологически было исследовано 65 больных приступообразно-прогредиентной параноидной

13 Kahana E., Kahana B., Zhang J. Motivational Antecedents of Preventive Proactivity in Late Life: Linking Future Orientation and Exercise // Motivation and Emotion, Vol. 29, № 4, December 2005; Kahana E., Kelley-Moore J., Kahana B. Proactive aging: A longitudinal study of stress, resources, agency, and well-being in late life // Aging \& Mental Healthю Vol. 16, № 4, May 2012, pp. 438-451.

14 Старченкова Е.С. Ресурсы проактивного совладающего поведения // Вестник Санкт-Петербургского университета. Серия 12: Психология. Социология. Педагогика. 2012. № 1. C. 51-61; Aspinwall, L.G. \& Taylor, S.E. (1997). A stitch in time: self-regulation and proactive coping. Psychological Bulletin, 121, 417-436; Hambrick E.P., McCord D.M. Proactive Coping and its Relation to the Five-Factor Model of Personality. // Individual Differences Research. 2010, Vol. 8, № 2, pp. 67-77.

15 Ерзин А.И. Проактивное поведение при некоторых психических заболеваниях: критерии, факторы формирования, типология // Психиатрия, психотерапия и клиническая психология. 2012. № 4. С. 64-77; Ерзин А.И. Проактивные личностные ресурсы у больных с острым нарушением мозгового кровообращения, находящихся на восстановительном лечении // Психология и психотехника. 2013. № 9. С. 889-896. шизофренией (код F20.01 по МКБ-10). Средний возраст респондентов составил 21,3 лет. В выборку вошло 42 мужчины и 23 женщины. Длительность заболевания - до 5 лет. Продолжительность госпитализации - от 1 до 6 недель.

Аппарат психодиагностического исследования включал в себя следующие методики: авторский пилотажный опросник «Проактивное поведение», методику «Определение деструктивных установок в межличностных отношениях» В.В. Бойко, тест «Смысложизненные ориентации» J. Crumbaugh и L. Maholick в адаптации Д.А. Леонтьева ${ }^{16}$ и «Ориентационную анкету» Б. Басса ${ }^{17}$. Результаты исследования были дополнены данными об уровне социального функционирования пациентов (оценивался лечащими по шкале Global Assessment of Functioning Scale (GAF) $)^{18}$.

Для определения негативных установок применялась методика «Определение деструктивных установок в межличностных отношениях». Методика была разработана В.В. Бойко для изучения дезадаптивных установок личности, касающихся ситуаций межличностного взаимодействия. Опросник состоит из 25 пунктов и включает следующие шкалы: «Завуалированная (скрытая) жестокость», «Открытая жестокость», «Обоснованный негативизм», «Брюзжание», «Негативный личный опыт общения».

Тест смысложизненных ориентаций (СЖО) был разработан Дж. Крамбо и Л. Махоликом. Методика направлена на изучение степени осмысленности жизни, способности индивида ощущать контроль над своей судьбой. Тест состоит из 20 пунктов и включает следующие шкалы: «Цели в жизни», «Процесс жизни», «Результат», «Локус контроля - Я», «Локус контроля - жизнь».

Для изучения направленности поведения также использовалась методика Б. Басса «Ориентационная анкета», разработанная в 1967 г. Методика состоит из 27 пунктов и включает 3 шкалы: «Направленность на себя», «Направленность на общение», «Направленность на дело».

16 Леонтьев Д.А. Тест смысложизненных ориентаций. М.: Смысл, 1992. 16 с.

17 Басс Б. «Ориентационная анкета» // Практикум по дифференциальной психодиагностике профессиональной пригодности. Учебное пособие / Под общ. ред. В.А. Бодрова. М.: ПЕР СЭ. 2003. С. 535-540.

18 Hall, R.C. Global assessment of functioning. A modified scale. Psychosomatics. 1995 May-Jun; 36(3): 267-75. 


\section{Клиническая психология}

Математико-статистическая обработка результатов исследования проводилась с использованием кластерного, корреляционного и регрессионного анализа.

\section{Результаты и их анализ}

Анализ распределения респондентов по уровню социального функционирования (согласно шкале GAF) выявил следующие особенности. У 15 больных $(23,07 \%)$ отмечался относительно компенсированный уровень социального функционирования, для которого ведущими признаками являются полная редукция психотических состояний в периоды ремиссии, неустойчивость резидуальных психопатологических симптомов, легкие нарушения в учебной и профессиональной деятельности ${ }^{19}$.

Для 34 пациентов (53,3\%) был характерен умеренно декомпенсированный уровень социального функционирования. Его признаками выступают: умеренные или выраженные психопатологические симптомы в ремиссии, трудности средней тяжести или серьезные нарушения в социальной, трудовой и/или учебной сферах жизнедеятельности.

У 16 человек $(24,61 \%)$ был констатирован выраженно-декомпенсированный уровень социального функционирования, характеризующийся глубокими изменениями личности, нередко в сочетании с остаточными психопатологическими симптомами, значительными нарушениями деятельности в различных сферах жизни, серьезными нарушениями в межличностных отношениях.

Выяснение личностных компонентов проактивного поведения у больных параноидной шизофренией позволило установить следующие особенности (табл. 1):

Качественный анализ структуры личностных предикторов проактивности, показал, что на первом месте по выраженности в группе больных шизофренией расположилась шкала «Метапотребности», описывающая мотивационные источники поведенческой активности. Когда речь идет о проактивном поведении, целесообразно обратить особое внимание на высшие гуманистические ценности и потребности, обозначенные в теории мотивации А. Маслоу как «метапотребности». Клинико-

19 Дереча В.А., Катан Е.А. Психопатологический профиль приступообразно-прогредиентной параноидной шизофрении и его влияние на социальное функционирование больных. Оренбург: ОрГМА, 2007. 27 с.
Таблица 1.

\section{Личностные предикторы проактивности у больных шизофренией по результатам методики «Проактивное поведение»}

\begin{tabular}{|l|c|c|}
\hline \multicolumn{1}{|c|}{ Шкалы методики } & M & SD \\
\hline Осознанность действий & 17,0 & 4,3 \\
\hline Прогнозирование последствий поведения & 10,3 & 4,4 \\
\hline Внутренний локус контроля & 26,0 & 5,2 \\
\hline Спонтанность & 15,4 & 4,7 \\
\hline Автономия в принятии решений & 20,0 & 5,8 \\
\hline Метамотивация & 36,1 & 3,9 \\
\hline Внутренняя детерминация поведения & 35,1 & 3,7 \\
\hline Конструктивная проактивность & 20,2 & 4,2 \\
\hline Деструктивная проактивность & 23,3 & 2,2 \\
\hline Индекс проактивности & 178,1 & 10,4 \\
\hline
\end{tabular}

психологические методы исследования позволили установить, что наиболее значимыми потребностями для обследованных больных являются потребность в развитии, познавательные мотивы, эстетические потребности. Мотивы, связанные с социальным взаимодействием, представлены значительно реже. При этом обращает на себя внимание склонность к уходу от социальных контактов, уплощение эмоциональной сферы личности, различные страхи и снижение общей активности.

На втором месте по степени выраженности расположилась шкала «Внутренняя детерминация поведения». Шкала отражает склонность человека моделировать свое поведение на основе собственных убеждений, идеалов и установок. Высокие значения по этой шкале могут быть свидетельством того, что обследованные пациенты в повседневной жизни стараются ориентироваться при выборе моделей поведения в основном на собственные установки, представления, взгляды, убеждения и ценностные ориентации. При этом отдельные установки и убеждения могут встраиваться в бредовую концепцию, приводя к искажению паттернов проактивности и негативно влияя на уровень социального функционирования.

На третьем месте по степени выраженности шкала «Внутренний локус контроля». Относительно невысокая выраженность показателей по этой шкале свидетельствует о недостаточно развитой склонности больных шизофренией брать на себя ответственность за происходящие с ними события. Клинико-психологическое исследование показывает, что далеко не все события своей жизни пациенты могут охарактеризовать как зависящие исключительно от их собственной воли. Больные 
часто испытывают тревогу и опасения за собственное здоровье, что приводит их к поиску информации о возможных причинах тех или иных заболеваний. В то же время ответственность за нарушения собственного здоровья больные шизофренией довольно часто перекладывают на т.н. «внешние силы», чей-то злой умысел и т.д.

На четвертом месте по степени выраженности оказалась шкала «Автономия в принятии решений». Низкие значения по данной шкале свидетельствуют об убежденности больных в том, что их выбор является недобровольным, а поведение контролируется другими людьми (например, «секретными организациями») или сверхъестественными силами («паранормальные явления», Бог, Сатана и пр.).

Существенно более низкие значения получены по шкалам «Спонтанность», «Осознанность действий» и «Прогнозирование последствий поведения». Последние две шкалы, по нашему мнению, являются взаимосвязанными и отражают рефлексивную сторону психики. При шизофрении функция рефлексии оказывается нарушенной. Это приводит к необдуманным, импульсивным поступкам, нередко угрожающим физическому и психологическому благополучию как самих больных, как и их социального кружения. Шкала «Спонтанность» отражает способность действовать на основании внутренних побуждений, а не только отталкиваясь от внешних обстоятельств. Больные шизофренией нередко ведут себя достаточно скованно, ограничивая себя в проявлениях и высказываниях. Естественная спонтанность, характерная для здоровых людей, здесь проявляется в значительно меньшей мере.

Анализ данных по дополнительным шкалам методики, отражающим направленность личности, не выявил достоверных различий между конструктивными и деструктивными тенденциями.

Кластерный анализ интегральных показателей проактивного поведения в группе больных шизофренией позволил разделить их на три кластера по уровню индекса проактивности (табл. 2).

Таблица 2.

Распределение больных шизофренией по кластерам в зависимости от индекса проактивности

\begin{tabular}{|c|c|c|c|c|}
\hline Кластеры & $\mathbf{N}$ & $\mathbf{\%}$ & $\mathbf{M}$ & SD \\
\hline 1 & 6 & 9,2 & 203,17 & 10,61 \\
\hline 2 & 46 & 70,8 & 178,63 & 1,97 \\
\hline 3 & 13 & 20,0 & 164,64 & 4,44 \\
\hline
\end{tabular}

Корреляционный анализ с применением r-критерия Пирсона показал наличие тесной положительной связи между интегральным показателем проактивности и уровнем социального функционирования ( $\mathrm{r}=.738$ на уровне значимости .001). При высоких значениях индекса проактивности при шизофрении в основном отмечается относительно компенсированный уровень социального функционирования (СФ). При средних значениях наблюдается умеренно декомпенсированный уровень СФ. При низких значениях указанного параметра у всех обследованных больных выявлен выраженно-декомпенсированный уровень СФ.

С помощью методики В.В.Бойко нами было установлено, что у больных шизофренией в отношениях с окружающими преобладает в основном завуалированная, скрытая агрессивность и жестокость (таблица 3). Данный показатель, возможно, коррелирует с враждебностью и чувством недоверия. Современные исследователи показывают ${ }^{20}$, что уровень враждебности при шизофрении достоверно более высок по сравнению с нормой. Завуалированная жестокость проявляется в недоверчивости, в опасениях, в предубеждениях по отношению к конкретным людям или группе людей. Эта личностная черта также находит свое выражение в фантазиях больных, в которых они совершают жестокие, насильственные действия над другими людьми.

Таблица 3.

\section{Результаты исследования деструктивных установок, проявляющихся в межличностных отношениях у больных шизофренией}

\begin{tabular}{|l|c|c|c|}
\hline \multicolumn{1}{|c|}{ Показатели } & $\begin{array}{c}\text { Мак- } \\
\text { симум } \\
\text { баллов }\end{array}$ & $\begin{array}{c}\text { Показатели } \\
\text { в группе боль- } \\
\text { ных шизофре- } \\
\text { нией M (SD) }\end{array}$ & $\begin{array}{c}\text { \% от мак- } \\
\text { симального } \\
\text { кол-ва } \\
\text { баллов }\end{array}$ \\
\hline $\begin{array}{l}\text { Завуалированная } \\
\text { жестокость }\end{array}$ & 20 & $16,64(2,06)$ & 83,2 \\
\hline Открытая жесткость & 45 & $17,03(4,25)$ & 37,8 \\
\hline $\begin{array}{l}\text { Обоснованный } \\
\text { негативизм }\end{array}$ & 5 & $2,2(1,09)$ & 44 \\
\hline Брюзжание & 10 & $7,38(1,67)$ & 73,8 \\
\hline $\begin{array}{l}\text { Негативный опыт } \\
\text { общения }\end{array}$ & 20 & $15,02(2,96)$ & 75,1 \\
\hline
\end{tabular}

На втором месте по степени выраженности шкала «Негативный опыт общения». Данная шка-

20 Кузнецова С.О. Психологические особенности враждебности при психической патологии // Вопросы психологии. 2007. № 5. С. 89-99. 


\section{Клиническая психология}

ла демонстрирует убежденность больных в том, что их взаимоотношения с другими людьми в прошлом складывались неудачно.

На третьем месте - шкала «Брюзжание», отражающая склонность делать необоснованные выводы и сверхобобщения негативных фактов относительно взаимоотношений с другими людьми и социальной действительности в целом. Высокие показатели по данной шкале, по нашему мнению, связаны с одной из наиболее распространенных дисфункциональных установок и когнитивных ошибок, влияющих на формирование депрессивных состояний.

Исследование смысложизненных ориентаций с помощью методики СЖО позволило установить (рис. 1), что для обследованных больных свойственно отсутствие четких целей в жизни, которые придавали бы ей осмысленность, направленность и временную перспективу. Об этом свидетельствуют относительно невысокие значения по шкале «Цели в жизни».

Низкие значения получены по шкале «Локус контроля - жизнь». Это указывает на то, что больные шизофренией убеждены в неподвластности своей жизни сознательному контролю, у них присутствует вера в фатализм и бессмысленность планирования своего будущего. Данный показатель также подтверждает доводы в пользу низкого уровня проактивности при шизофрении, поскольку проактивное поведение проявляется, в первую очередь, умением ставить личностно-значимые цели, планировать будущее, основываясь на убеждении в том, что жизнь и судьба являются результатом собственных усилий, а не внешних условий и обстоятельств.

Низкие значения выявлены по шкале «Локус контроля - Я». Это свидетельствует о преобладании у больных шизофренией представлений о том, что они не являются сильными личностями, способными самостоятельно влиять на свою судьбу. Обследованные больные полагают, что не обладают достаточной свободой выбора, чтобы строить свою жизнь в соответствии с собственными целями, ценностями и смыслами.

Сравнительно более высокие значения были получены по шкале «Результативность жизни», описывающей представления респондентов о степени продуктивности и осмысленности прожитой жизни. Относительно высокие по сравнению с другими шкалами показатели по этой шкале могут означать, что больные шизофренией испыты-

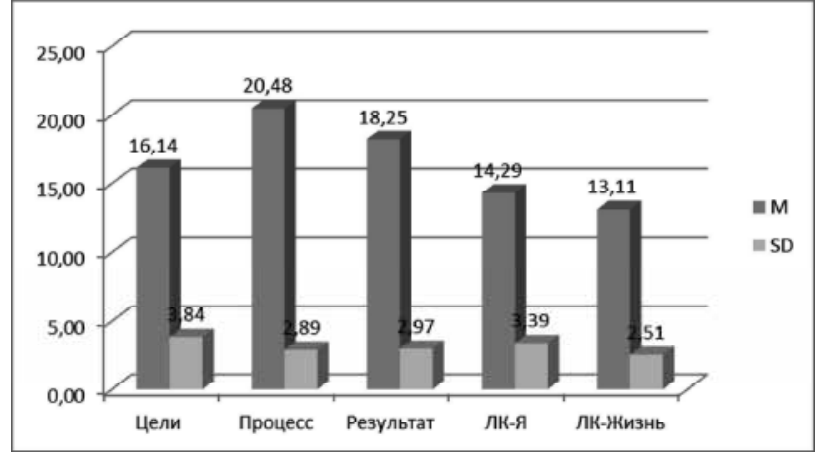

Рис. 1. Результаты исследования смысложизненных ориентаций у больных шизофренией по методике СЖО.

вают осознание того, что их жизнь в прошлом не лишена смысла.

Наиболее высокие значения обнаружены по шкале «Процесс жизни», отражающей ощущение эмоциональной насыщенности жизни. Относительно высокие результаты по этой шкале выражают концентрацию больных на настоящем, удовлетворенность лишь текущими событиями.

В целом, у больных шизофренией наблюдается снижение уровня проактивности за счет дефицита в сфере смысложизненных ориентаций. На первый план среди личностных компонентов самодетерминированного поведения выступают такие характеристики, как снижение способности ставить цели в будущем, неверие в свои силы и убежденность в том, что собственная жизнь не поддается сознательному контролю.

Исследование ценностной направленности по методике Б. Басса показало (рис. 2), что для больных шизофренией характерна более выраженная ориентация на себя $(\mathrm{M}=38,15, \mathrm{SD}=8,15)$, и менее выраженная на общение $(M=8,76, S D=3,45)$. Среднюю позицию в личностной ценностной направленности занимает ориентация на дело (M=32,3, SD=8,39).

Ориентация на себя отражает интровертированность, агрессивность и властность в отношениях, повышенную тревожность и мнительность. Шкала «Ориентация на общение» включает в себя такие характеристики, как стремление поддерживать контакты с другими людьми, направленность на совместную деятельность, склонность к социальному одобрению, а также потребность в эмоциональных отношениях и привязанностях. Показатели по данным шкалам характеризуют больных шизофренией с точки зрения погруженности в самих себя, ухода от эмоционального общения, прекращения социальных контактов, конфликтности, тревожности. 


\section{Психология и психотехника 6(69) • 2014}

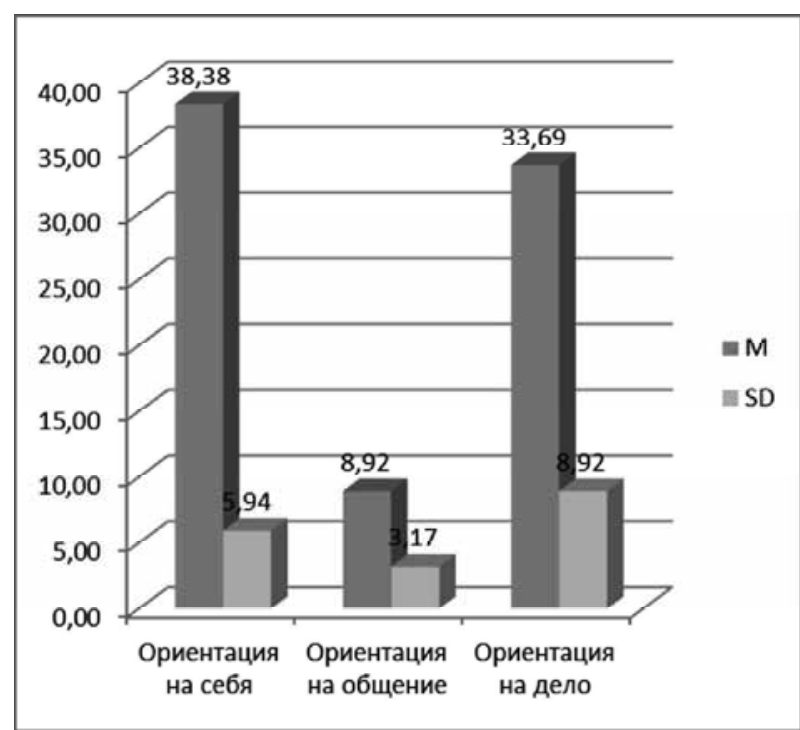

Рис. 2. Результаты исследования направленности личности больных шизофренией по данным «Ориентационной анкеты» Б. Басса.

Регрессионный анализ, направленный на изучение влияния ценностных и смысложизненных ориентаций на интегральный показатель проактивности, позволил уточнить (рис. 3), что у больных шизофренией индекс проактивности, оцениваемый по методике «Проактивное поведение», наиболее тесно связан с показателями «Цели в жизни» $\left(\mathrm{R}^{2}=.885\right)$, «Результативность жизни» $\left(\mathrm{R}^{2}=.893\right)$, «Локус контроля - Я» $\left(\mathrm{R}^{2}=.863\right)$, «Ориентация на общение» $\left(\mathrm{R}^{2}=.851\right)$ и «Ориентация на дело» $\left(\mathrm{R}^{2}=.859\right)$.

Тесная положительная взаимосвязь также была обнаружена между индексом проактивности и факторами «Процесс жизни» $\left(\mathrm{R}^{2}=.751\right)$ и «Локус контроля - Жизнь» $\left(\mathrm{R}^{2}=.752\right)$. Обратная корреляция выявлена между индексом проактивности и шкалой «Ориентация на себя» $\left(\mathrm{R}^{2}=-.792\right)$. Данное обстоятельство указывает на то, что проактивность проявляется в широком диапазоне межличностных контактов, в то время как низкие показатели проактивности связаны с тенденцией к уходу от социальных контактов.

\section{Выводы}

Изменения личности при шизофрении, затрагивающие когнитивную, эмоционально-волевую, мотивационно-потребностную и ценностно-смысловую сферы, объективно констатируются социальным окружением больных на основе внешне-поведен- ческих признаков, проявляющихся в глубоких трансформациях привычного стереотипа поведения, прежних интересов и увлечений, мотивов и ценностей. При этом проактивность, с нашей точки зрения, следует рассматривать как интегральную характеристику здоровой личности, определяющую способность к саморефлексии, антиципации и самодетерминации. Однако при шизофрении (как и при некоторых других видах психической патологии, включая депрессивный синдром, органическое снижение личности, наркозависимость и пр.), количественные показатели проактивности зачастую оказываются значительно ниже по сравнению с нормой ${ }^{21}$. Критериями диагностики снижения уровня проактивности у больных могут служить как выявленные в ходе анамнестического исследования или на основе самоотчетов пациентов качественные особенности изменения поведенческой активности, так и данные, полученные от родственников больных.

Проведенное исследование показало, что при параноидной шизофрении на уровень проактивности оказывают негативное влияние такие факторы, как дезадаптивные установки и предубеждения, встроенные в бредовую концепцию, дефицитарность рефлексивной и прогностической функций, редуцированная способность планировать отдаленное будущее, низкая спонтанность, отсутствие ощущения контроля над собственной жизнью, тенденция к избеганию межличностных контактов. Снижение проактивности, в свою очередь, влияет на уровень социального функционирования больных, который в большинстве случаев является умеренно декомпенсированным.

Проактивность при шизофрении отличается заметно более низкими показателями в сравнении с нормой. При этом отсутствие у обследованных больных психологически понятных устойчивых жизненных целей и смыслов, а также убежденность в том, что их собственное будущее не поддается сознательному контролю, приводят к преобладанию реактивных паттернов поведения над проактивными. В конечном счете, низкая проактивность, связанная с отсутствием продуктивных целей и смыслов жизни, приводит больных шизофренией к снижению числа социальных контактов,

21 Ерзин А.И. Проактивное поведение при некоторых психических заболеваниях: критерии, факторы формирования, типология // Психиатрия, психотерапия и клиническая психология. 2012. № 4. С. 64-77. 


\section{Клиническая психология}

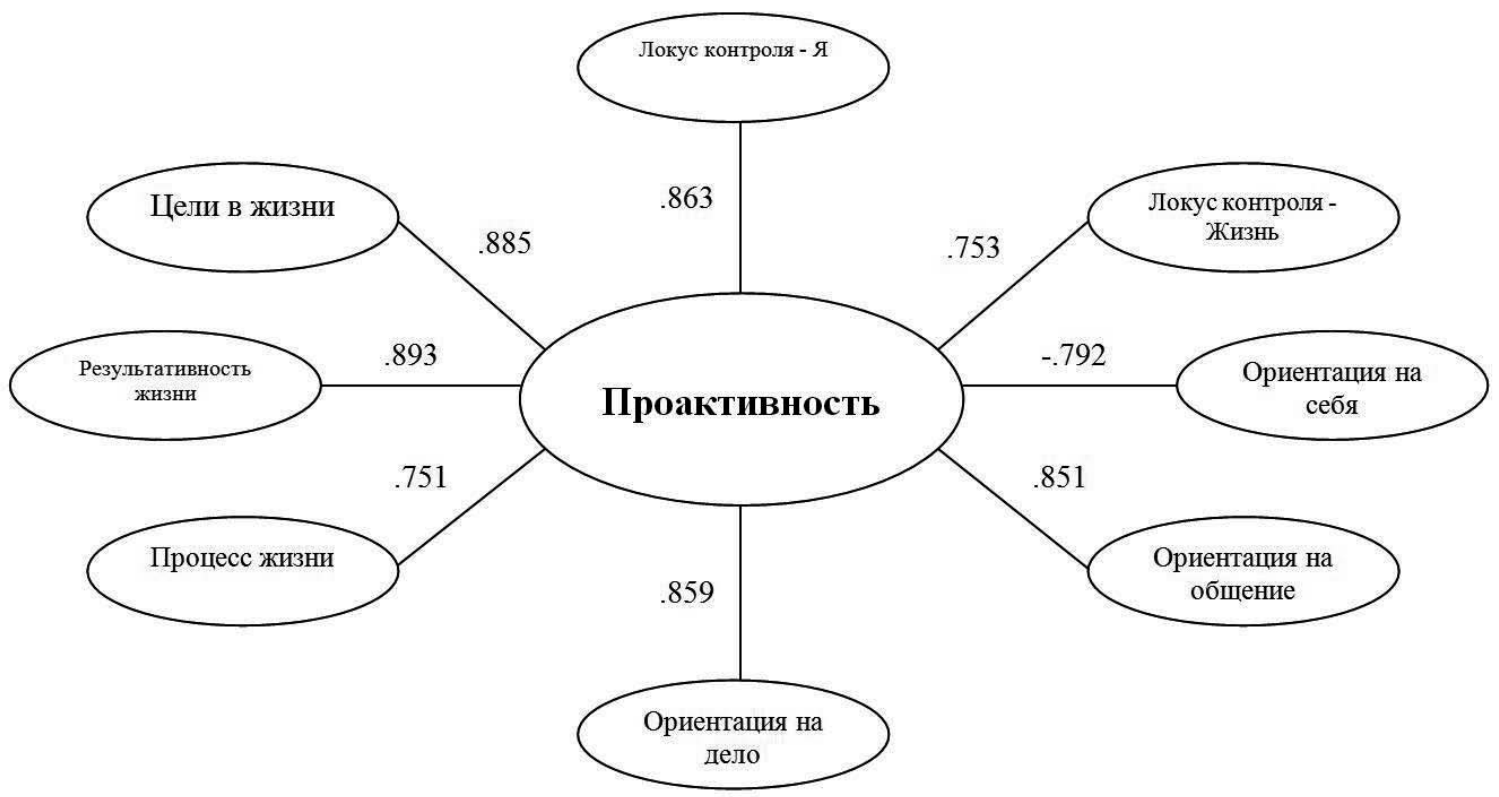

Рис. 3. Результаты регрессионного анализа ценностных и смысложизненных факторов проактивности у больных шизофренией.

к оскудению репертуара поведенческих реакций, к обеднению интересов, к последующей изоляции от общества. В тех случаях, когда у больных параноидной шизофренией отмечаются относительно более высокие показатели проактивности, мы констатируем доминирование в их поведении патологических интересов и увлечений, деструктивных установок и предубеждений, не только затрудняющих межличностное взаимодействие, но и зачастую делающих его невозможным. Несомненно, ведущую роль в искажении паттернов проактивного поведения играют и бредовые идеи воздействия, преследования, величия, изобретательства и т.д., в результате чего самодетерминация поведения больных инициируется неадекватными представлениями и установками, сверхценными идеями и навязчивостями. При этом поведение больных в большинстве случаев носит деструктивный характер, проявляющийся повышенной возбудимостью, агрессией, конфликтностью и заостренной тенденцией доказывать собственную правоту, игнорируя обстоятельства.

Таким образом, полученные результаты позволяют расширить представления о проактивности и ее личностных детерминантах в патопсихологии. Выявленные особенности личности рекомендуется использовать в качестве мишеней психотерапии и психокоррекции ${ }^{22}$.

\section{Список литературы:}

1. Акимова Е.В. Характеристика высших психических функций и неврологических расстройств у больных с дефицитарными состояниями при шизофрении. Автореф. дисс. ... канд. мед. наук. Н. Новгород, 2005. 23 с.

2. Басс Б. «Ориентационная анкета» // Практикум по дифференциальной психодиагностике профессиональной пригодности. Учебное пособие / Под общ. ред. В.А. Бодрова. М.: ПЕР СЭ. 2003. С. 535-540.

3. Гордеева Т.О. Теория самодетерминации: настоящее и будущее. Часть 1. Проблемы развития теории // Психологические исследования: электронный научный журнал. 2010. № 4(12). С. 11.

4. Гурович Н.Г. Соотношение положительных и отрицательных эмоций у больных шизофренией. Автореф. дисс. ... канд. психол. наук. М., 1986. 23 с.

22 Ерзин А.И. Динамика некоторых компонентов проактивности у больных шизофренией в процессе групповой психотерапии // Фундаментальные исследования. 2013. № 11-7. С. 1505-1508. 


\section{Психология и психотехника 6(69) • 2014}

5. Дереча В.А., Катан Е.А. Психопатологический профиль приступообразно-прогредиентной параноидной шизофрении и его влияние на социальное функционирование больных. Оренбург: ОрГМА, 2007. 27 с.

6. Ерзин А.И. Динамика некоторых компонентов проактивности у больных шизофренией в процессе групповой психотерапии // Фундаментальные исследования. 2013. № 11-7. С. 1505-1508.

7. Ерзин А.И. О проактивном совладающем поведении // NB: Психология и психотехника. 2013. № 1. C. 89-100. (http://www.e-notabene.ru/psp/article_274.html).

8. Ерзин А.И. Проактивное поведение при некоторых психических заболеваниях: критерии, факторы формирования, типология // Психиатрия, психотерапия и клиническая психология. 2012. № 4. C. 64-77.

9. Ерзин А.И. Проактивные личностные ресурсы у больных с острым нарушением мозгового кровообращения, находящихся на восстановительном лечении // Психология и психотехника. 2013. № 9. C. 889-896.

10. Ерзин А.И. Проблема проактивности в психологии здоровья // NB: Психология и психотехника. 2014. № 1. C. 94-124. (http://e-notabene.ru/psp/article_11536.html).

11. Ерзин А.И. Психологические особенности деструктивного поведения у больных шизофренией // Психология и психотехника. 2013. № 3. С. 288-293.

12. Ерзин А.И., Епанчинцева Г.А. Понятие проактивности в современной психологии // Теоретическая и экспериментальная психология. 2013. Т. 6. № 1. С. 79-83.

13. Кузнецова С.О. Психологические особенности враждебности при психической патологии // Вопросы психологии. 2007. № 5. С. 89-99.

14. Левикова Е.В. Социальная компетентность больных шизофренией подростков. Часть 1 // Психологические исследования: электрон. науч. журн. 2010. № 2(10). (http://psystudy.ru).

15. Леонтьев Д.А. Тест смысложизненных ориентаций. М.: Смысл, 1992. 16 с.

16. Лоскутова В.А. Социально-когнитивные функции при шизофрении и способы терапевтического воздействия // Социальная и клиническая психиатрия. 2009. Т. 19. № 4.

17. Рычкова О.В. Эмоциональные составляющие нарушений социальной перцепции при шизофрении // Социальная и клиническая психиатрия. 2012. Т. 22. № 4. С. 22-26.

18. Семенова Н.Д., Фурсов Б.Б. К вопросу о психодиагностике мотивации в психосоциальной терапии и психосоциальной реабилитации шизофрении. Часть I // Социальная и клиническая психиатрия. 2013. T. 23. № 1. С. 34-39.

19. Старченкова Е.С. Ресурсы проактивного совладающего поведения // Вестник Санкт-Петербургского университета. Серия 12: Психология. Социология. Педагогика. 2012. № 1. С. 51-61.

20. Фурсов Б.Б. Проблема мотивации и ее нарушений при шизофрении. // Социальная и клиническая психиатрия. 2012. Т. 22. № 4. С. 91-100.

21. Холмогорова А.Б., Гараньян А.Г., Данлыкова А.А., Шмуклер А.Б. Программа тренинга когнитивных и социальных навыков (ТКСН) у больных шизофренией // Социальная и клиническая психиатрия. 2007. T. 17. № 4.

22. Хоменко Н.В. Распознавание эмоций и память на лица у пациентов с шизофренией // Психиатрия, психотерапия и клиническая психология. 2012. № 4 (10). С. 46-55.

23. Чуркин А.А. Основные тенденции распространенности шизофрении в современном мире / ГНЦ социальной и судебной психиатрии им. В.П. Сербского. М., 2001.12 с.

24. Шостакович В.В., Блохина В.П., Белявский Н.Н. Критерий ранней диагностики шизофрении. Методическое письмо. Днепропетровск, 1972. 25 с.

25. Aspinwall, L.G. \& Taylor, S.E. (1997). A stitch in time: self-regulation and proactive coping. Psychological Bulletin, 121, 417-436.

26. Crant, J.M. (2000). Proactive behavior in organizations. Journal of Management, 26 (3), 435-462.

27. Deci, E.L., Vansteenkiste, M. (2004). Self-determination theory and basic need satisfaction: Understanding human development in positive psychology. // Ricerche di Psichologia, 27, 17-34.

28. Hall RC. Global assessment of functioning. A modified scale. Psychosomatics. 1995 May-Jun; 36(3): 267-75.

29. Hambrick E.P., McCord D.M. Proactive Coping and its Relation to the Five-Factor Model of Personality // Individual Differences Research.-2010, Vol. 8, No. 2, pp. 67-77. 


\section{Клиническая психология}

30. Kahana E., Kahana B., Zhang J. Motivational Antecedents of Preventive Proactivity in Late Life: Linking Future Orientation and Exercise // Motivation and Emotion, Vol. 29, No. 4, December 2005.

31. Kahana E., Kelley-Moore J., Kahana B. Proactive aging: A longitudinal study of stress, resources, agency, and well-being in late life. // Aging \& Mental Health Vol. 16, No. 4, May 2012,-pp. 438-451.

\section{References (transliteration):}

1. Akimova E.V. Kharakteristika vysshikh psikhicheskikh funktsii i nevrologicheskikh rasstroistv u bol'nykh s defitsitarnymi sostoyaniyami pri shizofrenii. Avtoref. diss. ... kand. med. nauk. n. Novgorod, 2005. 23 s.

2. Bass B. «Orientatsionnaya anketa»// Praktikum po differentsial'noi psikhodiagnostike professional'noi prigodnosti. Uchebnoe posobie / Pod obshch. red. V.A. Bodrova. M.: PER SE. 2003. S. 535-540.

3. Gordeeva T.O. Teoriya samodeterminatsii: nastoyashchee i budushchee. Chast' 1. Problemy razvitiya teorii // Psikhologicheskie issledovaniya: elektronnyi nauchnyi zhurnal. 2010. № 4(12). S. 11.

4. Gurovich N.G. Sootnoshenie polozhitel'nykh i otritsatel'nykh emotsii u bol'nykh shizofreniei. Avtoref. diss. ... kand. psikhol. nauk. M., 1986. $23 \mathrm{s.}$

5. Derecha V.A., Katan E.A. Psikhopatologicheskii profil' pristupoobrazno-progredientnoi paranoidnoi shizofrenii i ego vliyanie na sotsial'noe funktsionirovanie bol'nykh. Orenburg: OrGMA, 2007. 27 s.

6. Erzin A.I. Dinamika nekotorykh komponentov proaktivnosti u bol'nykh shizofreniei v protsesse gruppovoi psikhoterapii // Fundamental'nye issledovaniya. 2013. № 11-7. S. 1505-1508.

7. Erzin A.I. O proaktivnom sovladayushchem povedenii // NB: Psikhologiya i psikhotekhnika. 2013. № 1. S. 89-100. (http://www.e-notabene.ru/psp/article_274.html).

8. Erzin A.I. Proaktivnoe povedenie pri nekotorykh psikhicheskikh zabolevaniyakh: kriterii, faktory formirovaniya, tipologiya // Psikhiatriya, psikhoterapiya i klinicheskaya psikhologiya. 2012. № 4. S. 64-77.

9. Erzin A.I. Proaktivnye lichnostnye resursy u bol'nykh s ostrym narusheniem mozgovogo krovoobrashcheniya, nakhodyashchikhsya na vosstanovitel’nom lechenii // Psikhologiya i psikhotekhnika. 2013. № 9. S. 889-896.

10. Erzin A.I. Problema proaktivnosti v psikhologii zdorov'ya // NB: Psikhologiya i psikhotekhnika. 2014. № 1. S. 94-124. (http://e-notabene.ru/psp/article_11536.html).

11. Erzin A.I. Psikhologicheskie osobennosti destruktivnogo povedeniya u bol'nykh shizofreniei // Psikhologiya i psikhotekhnika. 2013. № 3. S. 288-293.

12. Erzin A.I., Epanchintseva G.A. Ponyatie proaktivnosti v sovremennoi psikhologii // Teoreticheskaya i eksperimental'naya psikhologiya. 2013. T. 6. № 1. S. 79-83.

13. Kuznetsova S.O. Psikhologicheskie osobennosti vrazhdebnosti pri psikhicheskoi patologii // Voprosy psikhologii. 2007. № 5. S. 89-99.

14. Levikova E.V. Sotsial'naya kompetentnost' bol'nykh shizofreniei podrostkov. Chast' 1 // Psikhologicheskie issledovaniya: elektron. nauch. zhurn. 2010. № 2(10). (http://psystudy.ru).

15. Leont'ev D.A. Test smyslozhiznennykh orientatsii. M.: Smysl, 1992. $16 \mathrm{s.}$

16. Loskutova V.A. Sotsial'no-kognitivnye funktsii pri shizofrenii i sposoby terapevticheskogo vozdeistviya // Sotsial'naya i klinicheskaya psikhiatriya. 2009. T. 19. № 4.

17. Rychkova O.V. Emotsional'nye sostavlyayushchie narushenii sotsial'noi pertseptsii pri shizofreniii // Sotsial'naya i klinicheskaya psikhiatriya. 2012. T. 22. № 4. S. 22-26.

18. Semenova N.D., Fursov B.B. K voprosu o psikhodiagnostike motivatsii v psikhosotsial'noi terapii i psikhosotsial'noi reabilitatsii shizofrenii. Chast' I // Sotsial'naya i klinicheskaya psikhiatriya. 2013. T. 23. № 1. S. 34-39.

19. Starchenkova E.S. Resursy proaktivnogo sovladayushchego povedeniya // Vestnik Sankt-Peterburgskogo universiteta. Seriya 12: Psikhologiya. Sotsiologiya. Pedagogika. 2012. № 1. S. 51-61.

20. Fursov B.B. Problema motivatsii i ee narushenii pri shizofrenii // Sotsial'naya i klinicheskaya psikhiatriya. 2012. T. 22. № 4. S. 91-100.

21. Kholmogorova A.B., Garan'yan A.G., Danlykova A.A., Shmukler A.B. Programma treninga kognitivnykh i sotsial'nykh navykov (TKSN) u bol'nykh shizofreniei // Sotsial'naya i klinicheskaya psikhiatriya. 2007. T. 17. № 4.

22. Khomenko N.V. Raspoznavanie emotsii i pamyat' na litsa u patsientov s shizofreniei // Psikhiatriya, psikhoterapiya i klinicheskaya psikhologiya. 2012. № 4 (10). S. 46-55. 


\section{Психология и психотехника 6(69) • 2014}

23. Churkin A.A. Osnovnye tendentsii rasprostranennosti shizofrenii v sovremennom mire / GNTs sotsial'noi i sudebnoi psikhiatrii im. V.P. Serbskogo. M., 2001. $12 \mathrm{~s}$.

24. Shostakovich V.V., Blokhina V.P., Belyavskii N.N. Kriterii rannei diagnostiki shizofrenii. Metodicheskoe pis'mo. Dnepropetrovsk, $1972.25 \mathrm{~s}$.

25. Aspinwall, L.G. \& Taylor, S.E. (1997). A stitch in time: self-regulation and proactive coping. Psychological Bulletin, 121, 417-436.

26. Crant, J.M. (2000). Proactive behavior in organizations. Journal of Management, 26 (3), 435-462.

27. Deci, E.L., Vansteenkiste, M. (2004). Self-determination theory and basic need satisfaction: Understanding human development in positive psychology. // Ricerche di Psichologia, 27, 17-34.

28. Hall RC. Global assessment of functioning. A modified scale. Psychosomatics. 1995 May-Jun; 36(3): 267-75.

29. Hambrick E.P., McCord D.M. Proactive Coping and its Relation to the Five-Factor Model of Personality // Individual Differences Research. - 2010, Vol. 8, No. 2, pp. 67-77.

30. Kahana E., Kahana B., Zhang J. Motivational Antecedents of Preventive Proactivity in Late Life: Linking Future Orientation and Exercise // Motivation and Emotion, Vol. 29, No. 4, December 2005.

31. Kahana E., Kelley-Moore J., Kahana B. Proactive aging: A longitudinal study of stress, resources, agency, and well-being in late life. // Aging \& Mental Health Vol. 16, No. 4, May 2012, — pp. 438-451. 